\title{
Opening Address to the Section of Architecture at the Newcastle Meeting
}

\section{Rev. Canon Raine}

To cite this article: Rev. Canon Raine (1885) Opening Address to the Section of Architecture at the Newcastle Meeting, Archaeological Journal, 42:1, 1-10, DOI: 10.1080/00665983.1885.10852162

To link to this article: http://dx.doi.org/10.1080/00665983.1885.10852162

$$
\text { Published online: } 15 \text { Jul } 2014 .
$$

Submit your article to this journal $\sqsubset \pi$

Q View related articles $₫$ 


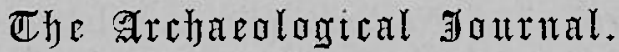

MARCH, 1885.

OPENING ADDRESS TO THE SECTION OF ARCHITECTURE AT THE NEWCASTLE MEETING. ${ }^{1}$

By REV. CANON RAINE.

In offering some preliminary remarks upon the great theme of Architecture, I shall try to avoid discursiveness, and endeavour to give a few descriptive hints and suggestions which wayfarers, such as we are, may find of some little use, as we inspect some of the chief objects of architectural interest which Northumberland can still exhibit. In that great county I must always feel an hereditary interest. It is out of the domain of history that I look upon the handiwork of ancient builders. The dates which the historian cliscovers are the framework upon which the whole system of architectural science is laicl down. It is history, likewise, which reproduces men and manners, feats of arms, and the achievements of the gentle life, without which stones are mere stones, and wood ancl water, the forest and the moor, lose half their charm. And there is added to, history in Northumberlancl the poetry of legend and tradition which invests tower and stream in this wide district with its own inimitable grace.

Domestic architecture in Northumberland from the very earliest times was the architecture of defence, as was the case, although to a less extent, upon the borders of Wales. The Roman wall-which I shall leave to its modern Hadrian, Dr. Bruce-the Roman wall, and the Roman fortified towns which guarded, or were strengthened by it,

${ }^{1}$ Delivered at Newcastle, August 6th, 1884.

voL. XLII (No. 165) 
all tell the same tale. The Picts and Scots who broke at times through that great barrier, or angled over it with their grappling hooks for the unwary legionary, were not a whit more restless and uncivilized than the rievers and mosstroopers who, in an after day, came down through the gaps in the hills into Redesdale or Tynedale, or carried terror and ruin into Norhamshire and Islandshire. And these marauders were in no degree worse than many of Northumbrians whom they plundered. Robbing and being robbed, century after century, produced a race of reckless, daring men whom no law could curb, and it was only after the accession of James of Scotland to the English throne that there was any sensible diminution in the long list of deeds of rapine and bloodshed on the Borders. In 1522 the Bishop of Carlisle, writing to Wolsey, says boldly: "There is more theft, more extortion by English thieves than by all the Scots in Scotland. No one, who is not in a stronghold, can keep any cattle or goods." This shows the absolute necessity for the towers and fortified houses with which Northumberland used to be filled. In that most able and valuable State-paper, the Survey of the Borders, drawn up by Sir John Forster in 1542, there is a complete picture of the materials for protection and defence which the county possessed. In Redesdale and Tynedale these towers and houses were often perched upon rocks, which a goat could scarcely climb; they were difficult of access also by reason of half-concealed roads, and made stronger still by hiding places and caves in the woods and hills. Their owners had a system of signals by which they could concentrate upon any point with an almost incredible speed, whilst there was everything to bewilder and entangle any daring foe who endeavoured to approach. In middle and northern Northumberland these towers were not secluded, but generally stood in the centre of some village or hamlet which clustered around them for protection. The dwellings of the poorer sort were usually of post and pan work covered with thatch, or mud sheelings still more miserable and rude. The tower was here and there called a peel or bastille, whilst you might see often a smaller building with a fortificd enclosure around it, called a barmkin, into which the cattle were driven for protection whenever a scry, as it was named, was raised. In 1468 
there were seventy-eight towers in the county, and in Sir John Forster's time there would probably be more, although many of them were in decay. Here and there the parsonage houses were places of defence, nay, the towers of the churches were used occasionally for the same purpose. Whenever the Scots were near, the cleric fled to his church, and, drawing up his ladder after him, shut down the trap-door and laughed at the foe who did not dare to stay long enough to burn him out. More potent than all these places in defence were the castles, which in 1468 reached the large number of thirty-seven. They were intended, not to ward off contending clansmen, but to be places of safety amid opposing armies. Berwick, Norham, Ford, and Wark guarded the lines of the Tweed and Till. On Berwick, Norham, and Newcastle the utmost skill of engineers and masons seems to have been exerted from Norman times throughout the middle-ages. In the mid-country there were Morpeth, Bothal, Mitford, Alnwick, Warkworth, and Dunstanborough. Alnwick, ever since it was built, has been the residence of the greatest family in the county and itself the greatest house. But I must not pass over Bambrough, with its glorious associations, the home of Saxon king and Norman baron, the screen which for many a long year sheltered the flickering beacon-light of religion upon the Holy Isle, and still happily consecrated by the superadded beneficence of a later age to the very highest purposes of true Christian philanthropy.

Thus far the architecture of Northumberland is that of war alone; and from the very earliest times to the beginning of the seventeenth century we have the record of local feuds and national strife, resulting frequently in bloodshed, and generating at all times hatred and alarm. Had religion no controlling power over the borderers? Not much, I fear, when we are told that the thieves were good church-goers, and that they were never more intent upon their devotions than on the eve of some great plundering foray or raid. The chapel of Bellingham was the great place of resort in upper Tynedale; the inhabitants held their public meetings and worshipped in it, after their fashion. When Wolsey put the churches in that district under an interdict, the clansmen, keenly sensitive about their spiritual welfare, employed a Scottish 
friar to minister to them the Sacraments. Nor clid the lieformation make any difference, at least not for a consiclerable time. At Tughill, near Bambrough, in 1599 and 1600 , three men, two of them bearing the ubiquitous name of Forster, were proceeded against in the Ecclesiastical court. One had struck the minister on th . head with his dagger ; another had fired a pistol among the congregation as it was leaving the chapel; and the third had deliberately ridden into the chapel on horseback whilst the service was going on. Such examples may be multiplied, but sufficient evidence has been given to show that whilst men did not know the difference between meum and turum, and right and wrong, religious progress was impossible. We must not imagine, however, that vast religious efforts were not made from the very earliest times. Putting aside the remains of British Christianity, of which Eddi speaks, I am inclined to think that the evangelization of Northumberland, in its present boundaries, was attempted by missionaries from Glasgow and Iona long before the work of Paulinus and the mission of Aidan. The first effort to reach it from the south was that of Paulinus from York, between 627 and 633 . The first permanent settlement in it from Iona was effected in 635, when the work of Paulinus had failed. Then Aidan, with his little band of followers, made himself a home at Lindisfarne, or Holy Island, under the shelter of the royal castle of Bambrough, from whence he could penetrate the mainland in every direction, and where he and his friends could lead, if they chose, their old ascetic lives in a place which was as wild almost as their old home at Iona. Tiningham, Coldingham, and Melrose became centres whence missionaries could go out to evangelize the Lothians. From Lindisfarne Aidan and his successors spread the Gospel in Northumberland. The work for a long time was mission work. The churches would be mainly baptisteries on the banks of rivers and streams. And as there was at that time no bishop at York, the Lindisfarne influence and teaching spread across the Tyne and Tees into Deira, or Yorkshire, itself, until it became practically coextensive with the kingdom of Northumbria. And at the same time that the first stone church between the Tees and the Firth of Forth was being raised at 
Lindisfarne, the pious care of Oswald, Aidan's patron in the north, was completing the first stone-built temple in Deira which Edwin had begun at York. After the year 664 the Lindisfarne prelates ruled no more in Yorkshire, and a new missionary effort on a grand scale was made from York upon the Tyne and Wear. The leaders of this movement were Wilfrid and Benedict Biscop, who, among other innovations, introduced Italian and French architecture and workmen into the north. The architecture of Lindisfarne was derived, through Iona, from Ireland. In this way a double influence (in addition to that from Cumbria or Glasgow) was brought to bear upon the architectural progress of Northumberland, and to show the fame of the workmanship on the Tyne and Wear, we have a notice in Bede, of Naitan, king of the Picts in the far north, sending thither for instructors in masonry and sculpture. We might expect to find, therefore, in Northumberland, or rather, in the kingdom of Northumbria, which covers a much wider area than the single county, a composite style of sculpture and architecture, peculiar to itself. And that this is the case, I must refer my hearers to the numerous specimens in the district of interlacing or basket work, as it has been called, of a most interesting kind. In many localities there are few churches in the walls of which such carvings have not been found, and in not a few churches there are remains of Saxon masonry as well. We have no Domesday book in the north to show what churches were then in existence, but I think that investigation, where documentary evidence fails us, will sooner or later show that wherever there was a parish church in the counties of Durham and Northumberland a century ago, there was a parish church on the same site in pre-Norman times. I may mention, with no small satisfaction, that there is every probability of these early sculptured remains being perpetuated by the graver's art at the cost of the University of Cambridge. This is a just tribute of respect to the country of Bede and Cuthbert. From Bcile came the idea of the great school or university of York, the mother of the universities of Europe. And from Northumbria came the Christianity of every kingdom in the Heptarchy excepting Kent, the Christianity too of Sweden and North Germany. The architectural remains 
of Saxon Northumbria, therefore, have an interest which we cannot estimate or measure. I trust most heartily that before this meeting closes some message of gratitude and promise of help may go forth to Cambridge, possessing, as that University already does, a thousand claims to the sympathy and respect of the old kingdom of Northumbria.

It is at Hexham that vou will find the most interesting remains in the county of Anglo-Saxon work, and you may mark the influence of the place in the churches in the neighbourhood, begimning with Ovingham. At Holy Island and Farne, still more sacred ground, there is little of that date ; there is next to nothing also at Tynemouth ; later building has obliterated or concealed it; but at Whittingham, Edlingham, Bolam, Whalton, Long Houghton, and other churches, you will find Saxon towers or masonry, whilst the interlacing sculpture meets your eye in many of the churches and churchyards.

The Norman era found the bishopric of Lindisfarne and Chester transferred to Durham, which renovated Jarrow and Wearmouth and rebuilt Lindisfarne, all of which the Danes had ruined. You may trace, also, the influence of Durham at this time in many churches in north Northumberland-nay, you may see the massive columnar work of Durham at Kirkby Lonsdale, at Cartmel, and in the crypt of York itself. St. Albans also established itself upon the cliff at Tynemouth, and acquired the churches of Eglingham and Hartburn, in the latter of which you may observe the Tynemouth influence. Newminster also sprang up on the Wansbeck in the twelfth century to plead for the Cistercians, but it had little or no effect upon the architecture of the county. A single arch is all that remains of the abbey itself. Hexham in postNorman times was under the control of York. But the monastic system did not prosper in the county. It was too disturbed and unsettled, and it was very difficult for the monks to get their rents paid. The little religious houses at Carham, Lambley, and Holystone were almost eaten up by the Scots, whilst Holy Island and Farne were always suffering and nearly always in debt. Hexham was on several occasions reduced to the very verge of ruin, and was only rescued from it by the well-paid up rents of its Yorkshire estates, on which it 
could always depend. Brinkburn was only a small place, and the religious houses at Alnwick clung for protection to the castle. Still, in spite of this turmoil and poverty, you may see at Tynemouth, Brinkburn, and Hexham fabrics of twelfth and thirteenth century work of remarkable beauty; and throughout the county, here and there, are choice specimens of mediæval architecture of various periods, often grievously mutilated, but showing that, if circumstances only had been different, the genius was there, and the readiness to evoke it as well. But what was it possible to do when the country was for centuries almost in a state of siege, and nothing, even of the most sacred kind, was secure? The Scottish inroads between 1290 and 1330 were of the most dreadful kind, and church after church was practically destroyed with the exception of the bare walls. There are, indeed, some very fine churches in the county, such as Norham, Bambrough, Alnwick, Morpeth, Mitford, Warkworth, St. Nicholas in this city, and a few others, but these owe their preservation in each case only to the happy propinquity of a castle, or fort, to which a wide berth was generally given. The Scots themselves built at one time, as if in cruel mockery, just across the Tweed, a church called Ladykirk, which could not be destroyed as there was not an inch of wood in it. A happy contrast this to the battered fabrics on the other side of the river. Battered indeed they were at most times, but, if possible, they suffered more from ill-usage and neglect in the sixteenth and seventeenth centuries than they did before, especially in middle and north Northumberland. The greater part of the ancient chapels were then disused and became ruined, whilst the fabric of the parish churches themselves was cruelly neglected, as every one strove to discard any obligation to repair it. The most necessary and simple appliances of worship were frequently wanting. The little chapel of Hebbron originated a proverb by its condition, "It's no a byword, like Hebbron kirk," and no wonder, as an archdeacon reported of it, that he found it held together by thirteen props of wood. But, speaking of archdeacons, let me say that many churches which had withstood the onsets of the Scots fell in the middle of the last century before the charge of an arch- 
deacon. It will scarcely be believed that this dignitary, who was in all other respects a most estimable person, actually desired the incumbents and churchwardens, for use as well as for ornament, to take the mullions out of the church windows and put in sashes instead, and that in many instances his directions were carried out.

And now let us contrast the condition in the last century with that of the present lay. There has certainly been a most remarkable change. In the archdeaconry of Lindisfarne nearly every church has been either rebuilt or restored within the last thirty years, not always wisely or well, but still assuredly not in the spirit of that Northumbrian vicar, whom I could name, who chiselled away a whole corbeltable formed of grotesque heads, as he thought his congregation looked too much at them when they ought to have been looking at him. In the archdeaconry of Northumberland there has been less done, but still a great deal. I am unwilling to criticize. I remember an old friend of mine making the caustic remark that medieval architects erected buildings which we are unable to restore. I do not agree with this, but I do think that in far too many cases ancient remains have not been sufficiently respected, and that modern architects have often entirely overlooked the feeling and character of the architecture of the district in the work which they carry out. Every county, nay, various parts of each county have architectural features peculiar to themselves, with which an architect ought at least to make himself acquainted. There is an unhappy phrase in vogue describing the. renovation of a church. "It has undergone restoration."It used to be "It has been beautified."-Now it is worse still "It has undergone restoration." Poor church, I often think, what pangs it must have suffered. The stones must surely have been crying out. Now I am not one of those who would retain even discomfort and decay, and keep their churches empty, rather than improve and preserve them. By all means make your church as fit as you can for the claims it has to meet, but do value the past a little more than has been the custom. The most dangerous person of all is he who loves uniformity of style, and in his fabric would reduce all styles to one. That man 
sacrifices the historical story of his church to a very foolish caprice. Generally speaking, church restorers have far too much latitude and freedom of action allowed to them. Now will you permit me, in conclusion, to make two or three practical suggestions.

1.-Let every bishop have the advice of an architectural expert, or experts, before any structural changes are made in any church. The wanton mischief that has been done in the absence of such a rule as this is lamentably great. I could give many instances. Take two. Twice have I known the rebuilding of particular parts of churches urged and adopted on the plea that they were tumbling down. In each case, instead of tumbling down, they obstinately refused to fall or be moved. Were they allowed to stand, as they were perfectly able to do? No; in each case the architect vindicated the correctness of his ecclesiastical diagnosis by blowing the part up with gunpowder :

2.-Whenever the fabric of a church is touched. let careful drawings and exact plans of the parts altered be first officially made and deposited in the Diocesan registry.

3.-Let greater attention be paid to monuments and inscriptions. They are being destroyed now-a-days by hundreds and by thousands. I would simply remark that the legal value of these inscriptions is second only to that of a parish register, nay, in many instances they are far more useful-and that it is illegal to destroy them.

To me it is most objectionable to see the monuments on a chancel floor sacrificed to an array of encaustic tiles, which in tone, colour, and comfort are infinitely inferior to the old gray or blue stones. Time was when such tiles were rarely seen out of a church, now you find them better laid and better cleaned in the passage of every second-rate hotel. Surely it makes the church itself more solemn to see that under your feet are lying the dead of former generations. Are their memorials to follow in the wake of far too many memorials in this shifting age, and perish with them? It is impossible, of course, I know that, to avoid the moving of such monuments occasionally, and if you spare them, time will not. I earnestly recommend that in all possible cases a full copy of the inscrip- 
tions in a church and churchyard be taken by the minister, and that the copy be deposited in the parish chest. If such a record be made, decay is obviated, and removal is robbed of much of its mischief. I am glad to say that this suggestion of mine has been already adopted in some cases, and I cannot see why it should not be very advantageously carried out in many more. 